\title{
Failure of a warehouse floor by subsoil settlement
}

\author{
Stawomir Kwiecien' ${ }^{1, *}$ \\ ${ }^{1}$ Department of Geotechnics and Roads, Faculty of Civil and Environmental Engineering, Silesian \\ University of Technology, Akademicka 5, 44-100 Gliwice, Poland
}

\begin{abstract}
This paper discusses the failure of a warehouse floor (with an approximate surface area of $1.550 \mathrm{~m}^{2}$ ) inside an industrial building with a total developed area of approx. $8.200 \mathrm{~m}^{2}$ along with the testing of the failure and its repair. Over ten-odd years of operation of the industrial building, its floor was found to develop non-uniform settlement with a maximum depth of approximately $150 \mathrm{~mm}$ from the original floor level. The completed survey inspections, geotechnical tests and FEM studies demonstrated that the root cause of these non-uniform settlement events was the foundation of the warehouse floor, built on a subsoil which featured high and long-term deformability. Given the investigated conditions, it was decided to modify the foundation of the new warehouse floor slab by reinforcing the subsoil with drilled micropiling. The calculations completed, test loading of a drilled micropile and on-site inspection of the warehouse flooring in use confirmed that the modification was rational.
\end{abstract}

\section{Introduction}

The design of floors in industrial buildings and facilities requires consideration of its actual operating loads. Goods stored inside of warehouse buildings may impose the following types of loads on the warehouse floor: localised or point loads (from storage racks), block loads (areas of uniformly distributed loads separated by gaps) and large-area uniform loads [1]. The exact load type (the plane dimensions of its area) determines the depth of the subsoil or substrate interfaced with the warehouse floor. One of the causes of damage or failure of industrial floors is the lack of subsoil reinforcement, leading to the subsoil falling short of the required SLS (service limit state) [2]. Each damage or failure of a floor system entails high costs of its repair and service unavailability of the building for the duration of repairs [1].

This paper discusses a case of warehouse floor failure caused by non-uniform settlement of its subsoil, which was composed of thin organic soil layers located across a depth of several metres. The repair method of the warehouse floor failure is also discussed.

\footnotetext{
${ }^{*}$ Corresponding author: slawomir.kwiecien@polsl.pl
} 


\section{Overview of the industrial building and its warehouse floor}

The industrial building which housed the failed warehouse floor featured approximately $8.200 \mathrm{~m}^{2}$ in developed surface area and a roof height of approx. $12 \mathrm{~m}$. The structure of the industrial building was made of pre-cast reinforced concrete (RF) units. The spot footings of the building structure rested on large-diameter RF piles. The spot footings served as the foundation for $50 \times 50 \mathrm{~cm}$ columns which supported pre-tensioned concrete transoms and purlins. The roofing was made from box profile metal sheet insulated from the top with rock wool, which itself was isolated with bitumen felt.

The structural design of the building provided that the flooring was to be built of class B35 concrete with a total thickness of $20 \mathrm{~cm}$ and laid on a substructure of unsorted broken aggregate, $30 \mathrm{~cm}$ thick, with a drainage layer of sand, $20 \mathrm{~cm}$ thick.

The industrial building housed a beverage production and bottling plant with a warehouse floor to store the finished products. The warehouse floor was approximately $36.8 \times 42.0 \mathrm{~m}$ in plane size (ca. $1.550 \mathrm{~m}^{2}$, see Fig. 1) and was the only section of the industrial building where the floor failed, as discussed herein.

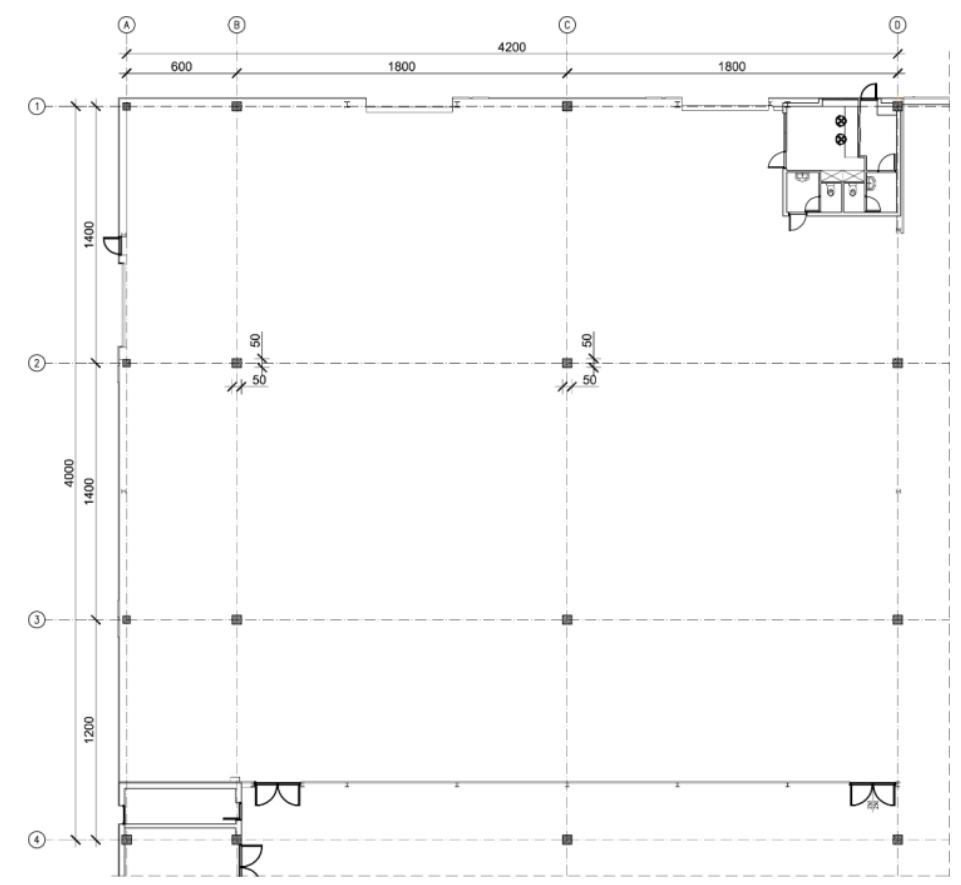

Fig. 1. View of the industrial building with the warehouse floor shown.

\section{The failure}

Over ten-odd years of use of the warehouse floor, a systematic development of non-uniform settlement was found at the location used to store pallets of finished drinks. Each pallet imposed a load of between 30 and $40 \mathrm{kPa}$. No settlement of the warehouse floor was found directly at the columns and at one of the corners of the building. The measured depth of settlement increased with the distance from the unaffected parts of the floor, with a maximum settlement depth of as much as approximately $150 \mathrm{~mm}$ below the original floor level. The settlement inhibited operation of forklift trucks and the storage of goods (see Figs. 2 and 3). 
The warehouse floor affected by the settlement developed numerous cracks and faults (Fig. 4). It was decided to overhaul the warehouse floor.

External walls also showed typical minor damages near the windows [3, 4] and in the middle of the length $[5,6]$.

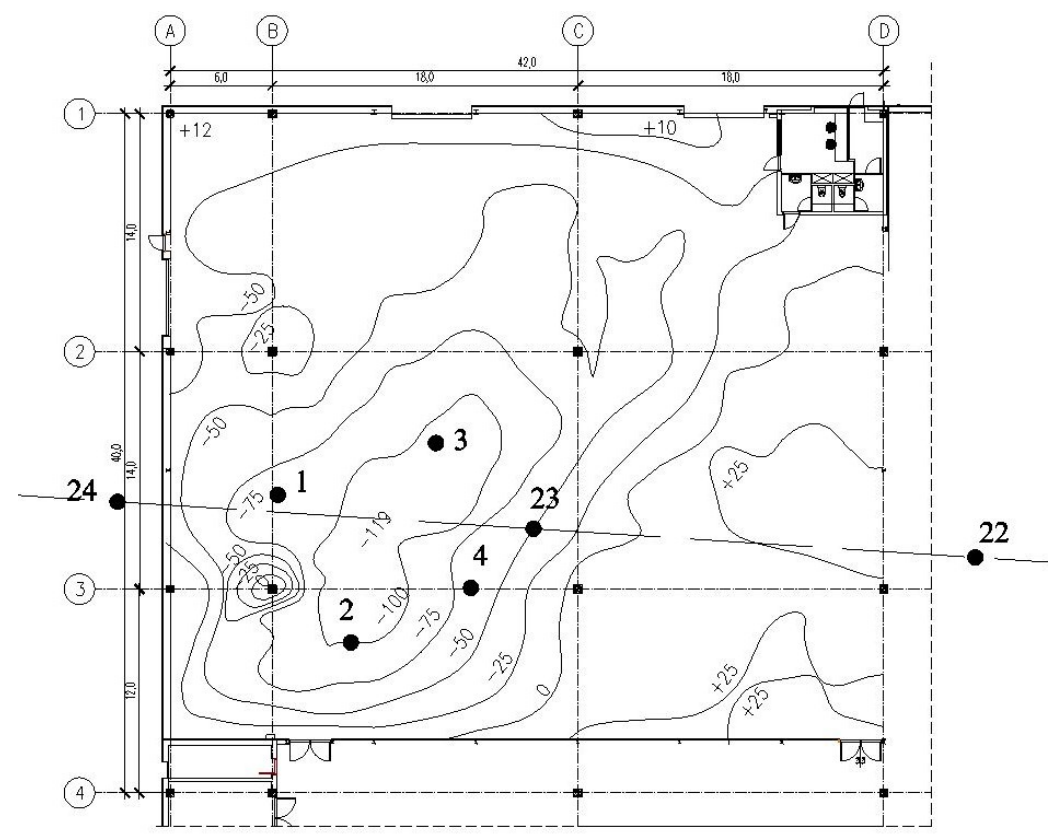

Fig. 2. Isolinear map of settlement of the warehouse floor with the test locations shown.
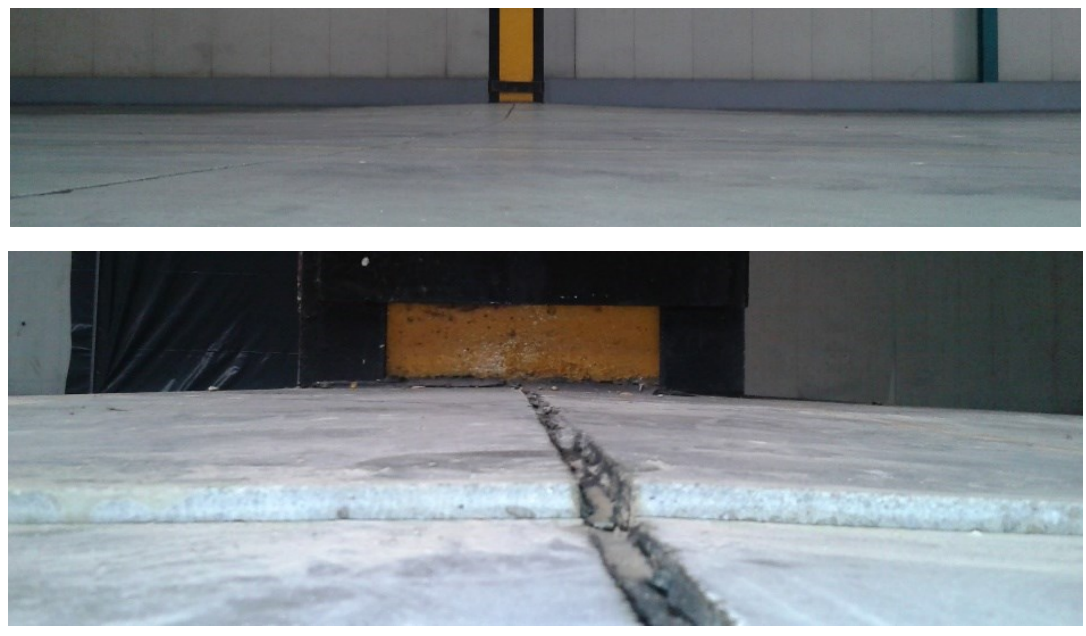

Fig. 3. Irregularities (faults) of the warehouse floor surface. 


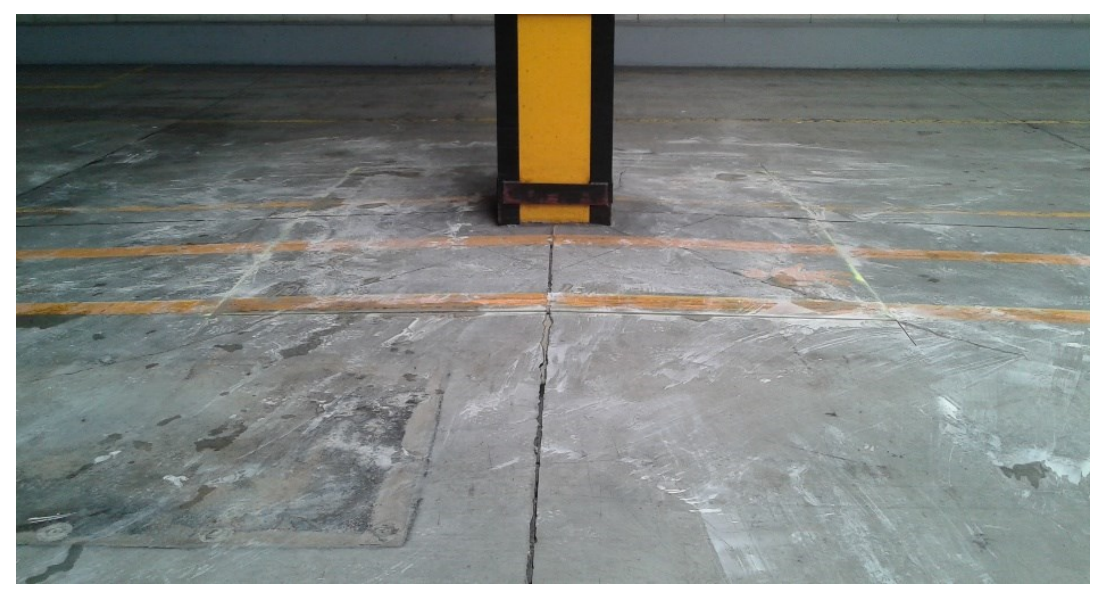

Fig. 4. Cracks on the warehouse floor surface.

\section{Soil and water conditions}

The subsoil under the failed warehouse floor was surveyed twice. The first survey was performed at the end of the 1990s, during the design of the industrial building. The second survey was performed in 2016, following the failure of the warehouse floor, and prior to its repair.

The first survey included opening 28 exploratory boreholes, each to a depth of $10 \mathrm{~m}$ below the terrain level (with the exception of one, opened down to $6.5 \mathrm{~m}$ below the terrain level). The first survey revealed soil of poor load-bearing capacity and poor stiffness (including peat soil, aggregate mud and humus soil). In order to establish their envelope, 9 additional exploratory boreholes were opened down to a depth of 4.5-7.0 m below the terrain level. The subsoil under the failed portion of the warehouse floor was surveyed with a total of 16 exploratory boreholes, which, given the warehouse floor area of approx. $1.550 \mathrm{~m}^{2}$, leads to the legitimate conclusion that the survey was rather detailed. During the opening of the exploratory boreholes, macroscopic tests were carried out along with monitoring of the ground water level. Samples were taken from the boreholes to test the physical characteristics of the surveyed soil types (grain size, moisture content, density, and consistency limits). The mechanical performance of most of the surveyed soil types were determined with Method B provided in PN-81/B-3020 [7] (from the test results for liquidity index and the assumed relative density). Some soil types had no strength or deformation parameters determined or reported (this included peat soil and uncompacted fill).

As suggested by the completed tests (see Fig. 2, items 22 to 24), the subsoil within the failed warehouse floor limits was made from four primary groups of soil types, each with a different strength and stiffness (see Fig. 5). The first primary group included uncompacted fill, which varied in grain size and condition (most of the fill was loose). The uncompacted fill was present from the terrain level to a depth of 2 to $3.5 \mathrm{~m}$. The second primary group included soils of alluvial and lacustrine origin, developed as cohesive and organic soil present down to approx. $4.7 \mathrm{~m}$ below the terrain level. The group included peat soil, hard-plastic to plastic dayey warp, and plastic silty clay with some humus. Below it and down to approx. $9.5 \mathrm{~m}$ below the terrain level, moderately compacted gravel was present with some field stones and clay (formations generated by alluvial accumulation). Deeper down was weathered shale with sandy shale, followed by solid rock below. During the opening of the boreholes in the layer of sand, an upper surface of a confined aquifer was found at approx. 3.5 to $4.4 \mathrm{~m}$ of depth, which stabilised itself at approx. 1.8 to $2 \mathrm{~m}$ of depth. 


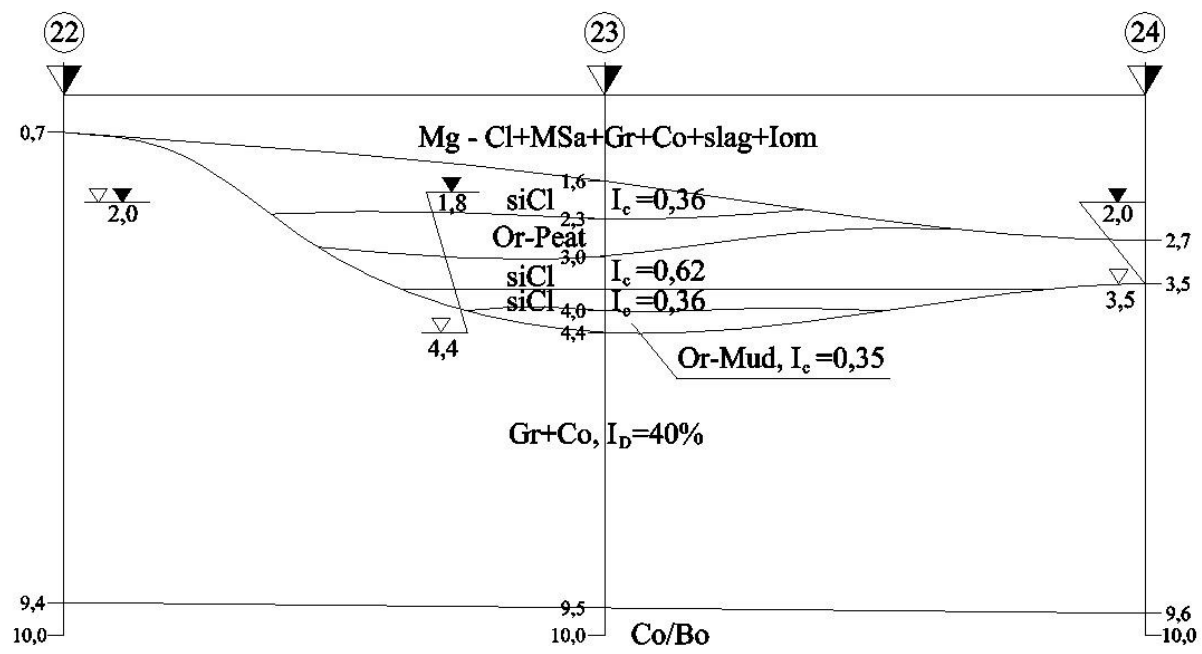

Fig. 5. Soil and water conditions under the failed warehouse floor.

The geotechnical survey documentation featured a proposal to build an intermediate foundation (formed by piling, for example) atop of the layer of gravel, or, alternatively, to replace weak and low-stiffness soil deposited down to $5 \mathrm{~m}$ below the terrain level.

These proposals were partially executed. The industrial building structure rested on dia. $1.2 \mathrm{~m}, 8.5 \mathrm{~m}$ long piles (which were themselves rested on moderately compacted gravel). The flooring system layers rested only on partially replaced soil.

The cumulative failure of the warehouse floor forced the project owner to have it repaired. Prior to the repair design and execution, the second survey was completed. The second survey included testing at four locations (see Fig. 2, items 1 to 4) located where the flooring settlement was the highest. First, the survey included probing with a DPH dynamic penetrometer, followed by mechanical boring. The surveyed depth was $6 \mathrm{~m}$ below the terrain level. The warehouse flooring level at the time of the second survey was approximately several dozen centimetres above the terrain level before the construction of the industrial building. The survey testing revealed that the warehouse floor, a two-layer system with a total thickness of approx. $32 \mathrm{~cm}$, was founded on a 1 to $1.7 \mathrm{~m}$ deep structural fill, formed by compacted sand varying in grain size, 0.07 to $0.35 \mathrm{~m}$ deep, and a layer of moderately compacted gravel with field stones. The second layer was loose at its bottom. The top of the structural fill was reinforced with a synthetic geomesh. Below the two foregoing layers were layers of uncompacted fill, formed by loose sand, loose bottom ash and loose rubble, with an overall thickness of between 0.7 and $2.1 \mathrm{~m}$, and thin layers (approx. $0.3 \mathrm{~m}$ thick) of hardplastic and semi-cohesive clay. The foregoing was underpinned with peat soil, dayey warp and plastic silty clay with humus, all down to a depth of 4.6-5.4 m below the terrain level. The thickness of the peat soil at the test site varied between 0 to $1 \mathrm{~m}$. Below this layer, moderately compacted cohesionless soil was found. The water conditions surveyed were very much like those found during the first survey. 


\section{Failure root cause analysis}

A FEM analysis was performed in the Z_Soil software [8] to determine the effect of the soil and water conditions on the discovered settlement of the warehouse floor. Given that the actual loads were applied to a large surface area of the failed warehouse floor, a 3-D model of a part of the floor was generated for the FEM analysis to reflect the floor response within the axis of loading (see Fig. 6). The material model of continuous elements, or the home soil and fill layers, was assumed to be an elastic and perfectly plastic model with a Coulomb-Mohr boundary surface and non-associated flow rule. The concrete elements (the warehouse floor) was a linear elastic model. The soil and water conditions and certain parameters of constitutive models were chosen for the FEM analysis according to the foregoing geotechnical survey documentation. The documentation specified no performance of the uncompacted fill layers (Ie) or the peat soil layers (IIa). The performance of both was determined by reverse analysis. The reverse analysis was based on the found and surveyed settlement of the warehouse flooring. The selection criteria applied to the performance was to generate calculated settlement with dimensions approximate to the actual one. Table 1 lists the performance parameters of the adopted constitutive models - both as assumed and determined with the reverse analysis. The FEM analysis demonstrated that the compliance of settlement (see Fig. 7) was achieved for a modulus of elasticity at approx. $0.5 \mathrm{MPa}$ for the peat soil layers and approx. $2 \mathrm{MPa}$ for the uncompacted fill layers.

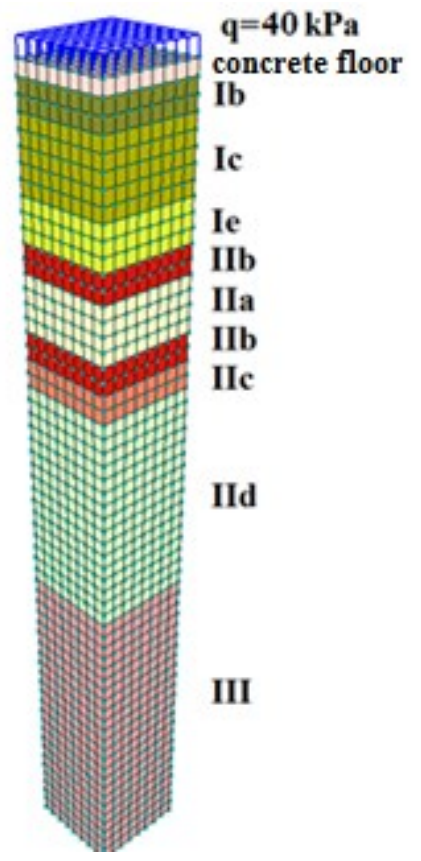

Fig. 6. FEM model. 
Table 1. Constitutive models and the performance parameters as assumed and determined in the FEM analysis.

\begin{tabular}{|c|c|c|c|}
\hline$\#$ & Type & $\begin{array}{c}\text { Assumed } \\
\text { constitutive } \\
\text { model }\end{array}$ & $\begin{array}{l}\text { Model performance } \\
\text { parameters }\end{array}$ \\
\hline 1. & $\begin{array}{c}\text { Layer Ib } \\
\operatorname{Mg}\left(\mathrm{FSa}, \mathrm{I}_{\mathrm{D}} \geq 70 \%\right)\end{array}$ & Coulomb-Mohr & $\begin{array}{c}\mathrm{E}=60 \mathrm{MPa}, \phi=30^{\circ}, \mathrm{c}=0 \mathrm{kPa}, \\
\nu=0.25, \gamma=18 \mathrm{kN} / \mathrm{m}^{3}, \psi=0^{\circ}\end{array}$ \\
\hline 2. & $\begin{array}{c}\text { Layer Ic } \\
\operatorname{Mg}\left(\mathrm{Gr}+\mathrm{Co}, \mathrm{I}_{\mathrm{D}} \geq 40 \%\right)\end{array}$ & Coulomb-Mohr & $\begin{array}{c}E=80 \mathrm{MPa}, \phi=38^{\circ}, \mathrm{c}=0 \mathrm{kPa}, \\
\nu=0.25, \gamma=18 \mathrm{kN} / \mathrm{m}^{3}, \psi=8^{\circ}\end{array}$ \\
\hline 3. & $\begin{array}{c}\text { Layer Ie } \\
\mathrm{Mg}, \mathrm{I}_{\mathrm{D}} \leq 30 \%\end{array}$ & Coulomb-Mohr & $\begin{array}{c}\mathrm{E}=2 \mathrm{MPa}, \phi=28^{\circ}, \mathrm{c}=0 \mathrm{kPa}, \\
\nu=0.3, \gamma=18 \mathrm{kN} / \mathrm{m}^{3}, \psi=0^{\circ}\end{array}$ \\
\hline 4. & $\begin{array}{c}\text { Layer IIb } \\
\text { siCl, } \mathrm{I}_{\mathrm{c}}=0,62\end{array}$ & Coulomb-Mohr & $\begin{array}{l}E=25 \mathrm{MPa}, \phi=9^{\circ}, c=9 \mathrm{kPa}, \\
\nu=0.21, \gamma=17 \mathrm{kN} / \mathrm{m}^{3}, \psi=0^{\circ}\end{array}$ \\
\hline 5. & $\begin{array}{l}\text { Layer IIa } \\
\text { Or (Peat) }\end{array}$ & Coulomb-Mohr & $\begin{array}{c}\mathrm{E}=0.5 \mathrm{MPa}, \phi=5^{\circ}, \mathrm{c}=5 \mathrm{kPa} \\
\nu=0.3, \gamma=15 \mathrm{kN} / \mathrm{m}^{3}, \psi=0^{\circ}\end{array}$ \\
\hline 6. & $\begin{array}{c}\text { Layer IIc } \\
\text { FSa, } \mathrm{I}_{\mathrm{D}}=57 \%\end{array}$ & Coulomb-Mohr & $\begin{array}{c}\mathrm{E}=90 \mathrm{MPa}, \phi=31^{\circ}, \mathrm{c}=0 \mathrm{kPa} \\
v=0.24, \gamma=10 \mathrm{kN} / \mathrm{m}^{3}, \psi=1^{\circ}\end{array}$ \\
\hline 7. & $\begin{array}{c}\text { Layer IId } \\
\mathrm{Gr}+\mathrm{Co}, \mathrm{I}_{\mathrm{D}}=40 \%\end{array}$ & Coulomb-Mohr & $\begin{array}{c}E=150 \mathrm{MPa}, \phi=38^{\circ}, \mathrm{c}=0 \mathrm{kPa}, \\
\nu=0.3, \gamma=10.5 \mathrm{kN} / \mathrm{m}^{3}, \psi=8^{\circ}\end{array}$ \\
\hline 8. & $\begin{array}{l}\text { Layer III } \\
(\mathrm{Co} / \mathrm{Bo})\end{array}$ & Coulomb-Mohr & $\begin{array}{c}\mathrm{E}=200 \mathrm{MPa}, \phi=40^{\circ}, \mathrm{c}=0 \mathrm{kPa}, \\
\nu=0.23, \gamma=10 \mathrm{kN} / \mathrm{m}^{3}, \psi=10^{\circ}\end{array}$ \\
\hline 9. & Concrete flooring & Linear-elastic & $\mathrm{E}=30 \mathrm{GPa}, v=0.2, \gamma=25 \mathrm{kN} / \mathrm{m}^{3}$ \\
\hline
\end{tabular}

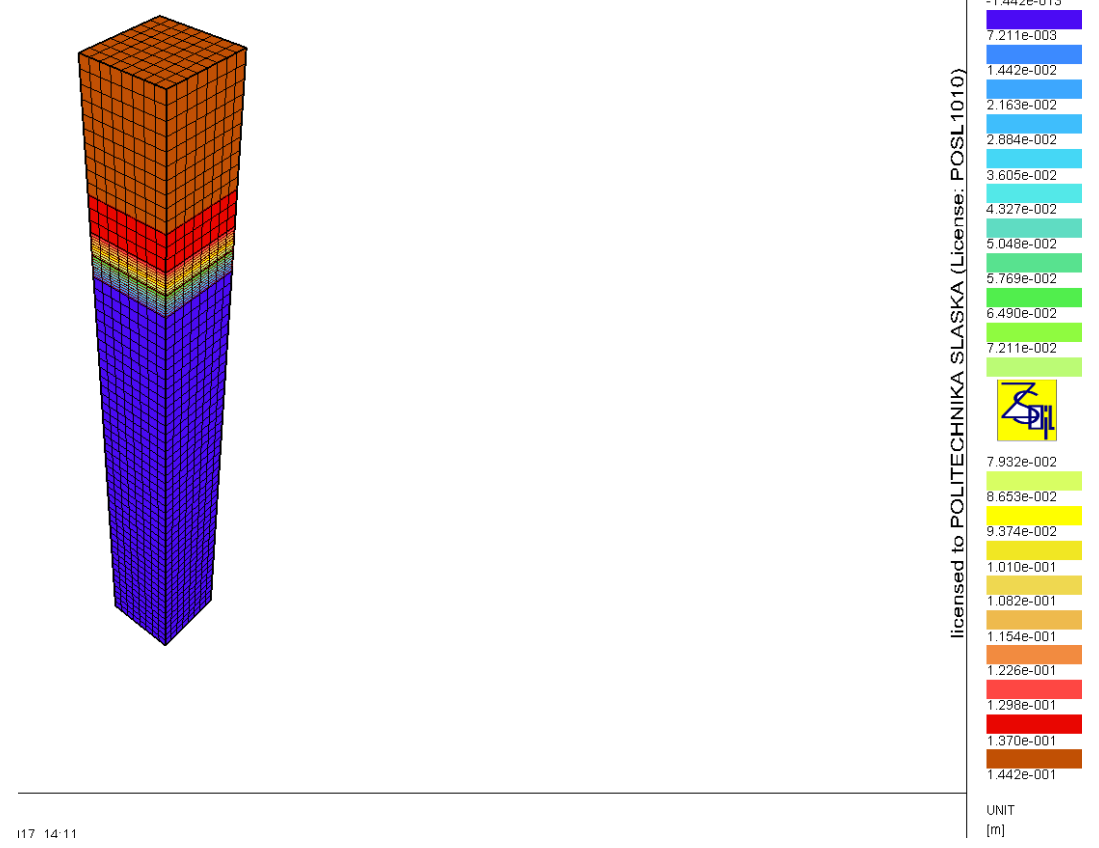

Fig. 7. Vertical displacement map; maximum settlement equal $145 \mathrm{~mm}$. 


\section{The repair}

The condition of the failed warehouse floor prompted a decision to repair it by complete replacement. The failure root cause analysis proved that the main root cause of non-uniform settlement was the organic soil (peat) layers present in the subsoil. Peat soils of this kind are prone to react with high deformability, which can be distributed across a long timeline (where reconsolidation is decisive). Peat soil may reveal unit volume variations of up to $50 \%$. Given the foregoing, prior to the repair work on the warehouse floor, it was decided to provide the subsoil with penetrating reinforcement which comprised drilled micropiling.

The micropiles were calculated according to the guidelines from a design guide published by Titan [9], including a determination of the load capacity of a driven micropile, a proof of ULS, and a selection of the ultimate skin friction capacity, $\mathrm{q}_{\mathrm{sk}}$, of the micropiles. The guidelines were based on the proprietary experience of the chosen micropiling contractor and PN-EN 1997-1:2008 [10].

The calculations assumed the potential for negative friction of the peat layers (ref. PN83/B-02482 [11]). Given this assumption, negative friction was also assumed for the layers above the peat soil (and designated as minus values in the calculations). The negative friction values were input at their maximum limits.

The diameter, spacing and length of the micropiling was selected to meet the conditions for ULS and SLS. The assumed maximum settlement of micropiling was not to exceed $10 \mathrm{~mm}$. The foregoing conditions were met, by FEM analysis, by micropiles with the following dimensions: $300 \mathrm{~mm}$ in diameter, $9 \mathrm{~m}$ in length, spaced on a $1.80 \times 1.85 \mathrm{~m}$ grid, the mesh of which was locally reduced at the expansion joints of the building structure (see Fig. 8 ). The lengthwise internal force of the micropiles was approximately $120 \mathrm{kN}$. The micropiles were reinforced with six \#16 lengthwise rebars, made from steel grade SAS 550/620-36. The transverse reinforcement of the micropiles was designed as a dia. 6 spiral with $20 \mathrm{~cm}$ in pitch.

The micropiles were made with RF cap blocks with a circular cross-section and $80 \mathrm{~cm}$ in diameter. In between the cap blocks, lean concrete was cast to level out the substructure for the new floor. The floor slab was built on a slip layer of plastic sheet.

The floor RF slab was calculated in the FEM software suite (see Fig. 9). It was assumed in the calculations that the areas in which no pallets with beverages $(\mathrm{q}=40 \mathrm{kPa})$ were stored, additional dynamic loads were imposed from the circulation of forklift trucks (with a front axle load at $86.08 \mathrm{kN}$ and a rear axle load at $11.37 \mathrm{kN}$ ), and the entire warehouse floor was exposed to a load from the shrinking of the fresh concrete (at a loading temperature of $15^{\circ} \mathrm{C}$ ). The new warehouse floor was designed and made from $22 \mathrm{~cm}$ thick $\mathrm{C} 25 / 30$ concrete. The top reinforcement mesh was formed by \#10 rebars, spaced every $15 \mathrm{~cm}$ crosswise and lengthwise. The bottom reinforcement mesh was formed by \#12 rebars, spaced every $15 \mathrm{~cm}$ crosswise and lengthwise. All rebars were made from \#RB500W rebar steel. To reduce the size of shrink cracks, the fresh concrete mix was designed with 12-mm long polypropylene fibres at a mass ratio to concrete of $0.6 \mathrm{~kg} / \mathrm{m}^{3}$. The warehouse flooring slab, $42.0 \times 36.84 \mathrm{~m}$ in size, was divided into four isolated fields (each $21.0 \times 18.42 \mathrm{~m}$ in size); the joints between the fields were made with expansion joint profiles (see Fig. 8). The top surface of the warehouse flooring slab was superficially cured, hardened and sealed.

The repair began in the autumn of 2017. See Fig. 10 for the photographic evidence of specific repair stages. 
Following the subsoil reinforcement, eight micropiles were chosen at random for the test loads. The load test method included fixed load increments. The assumed settlement stabilisation level was $0.05 \mathrm{~mm} / 10$ minutes. The maximum test load was $250 \mathrm{kN}$. The settlement between the tested micropiles varied from 3.11 to $4.09 \mathrm{~mm}$, and none exceeded the maximum limit of $10 \mathrm{~mm}$. After one year of operation of the repaired warehouse flooring (see Fig. 11), it was found to meet the SLS conditions.

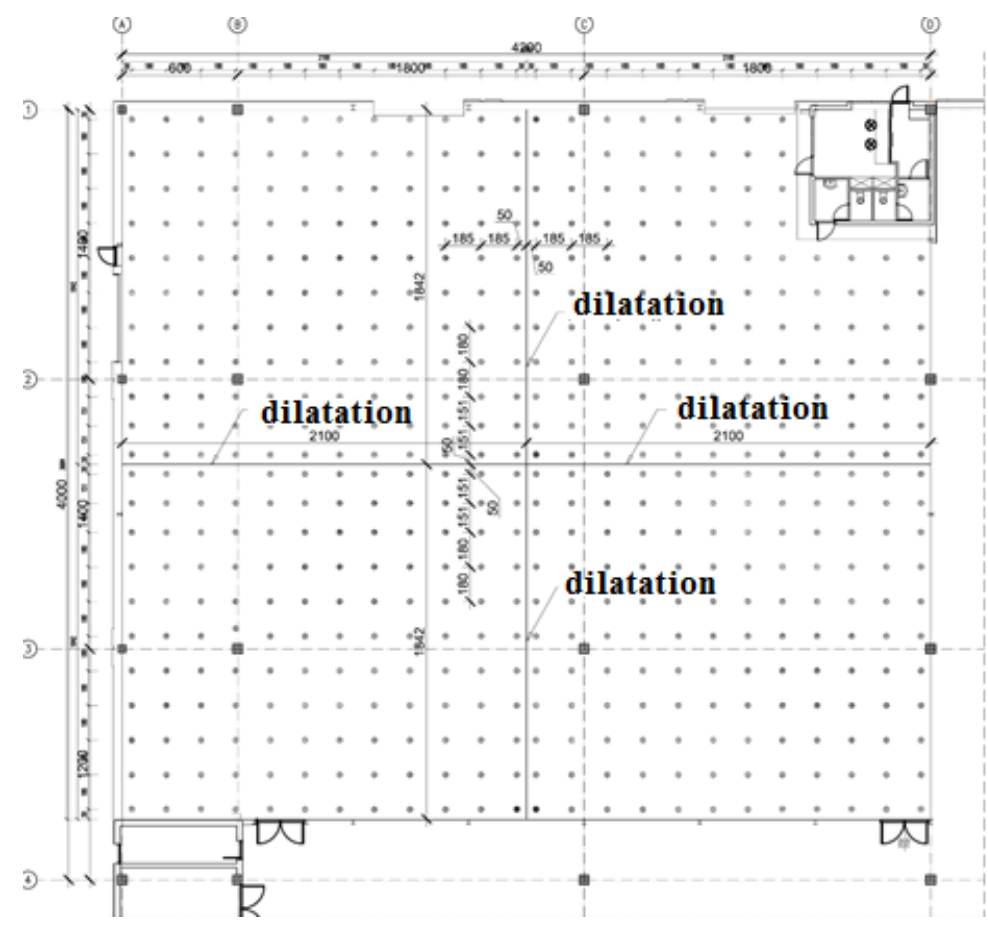

Fig. 8. Layout of the warehouse flooring micropiling and expansion joints.

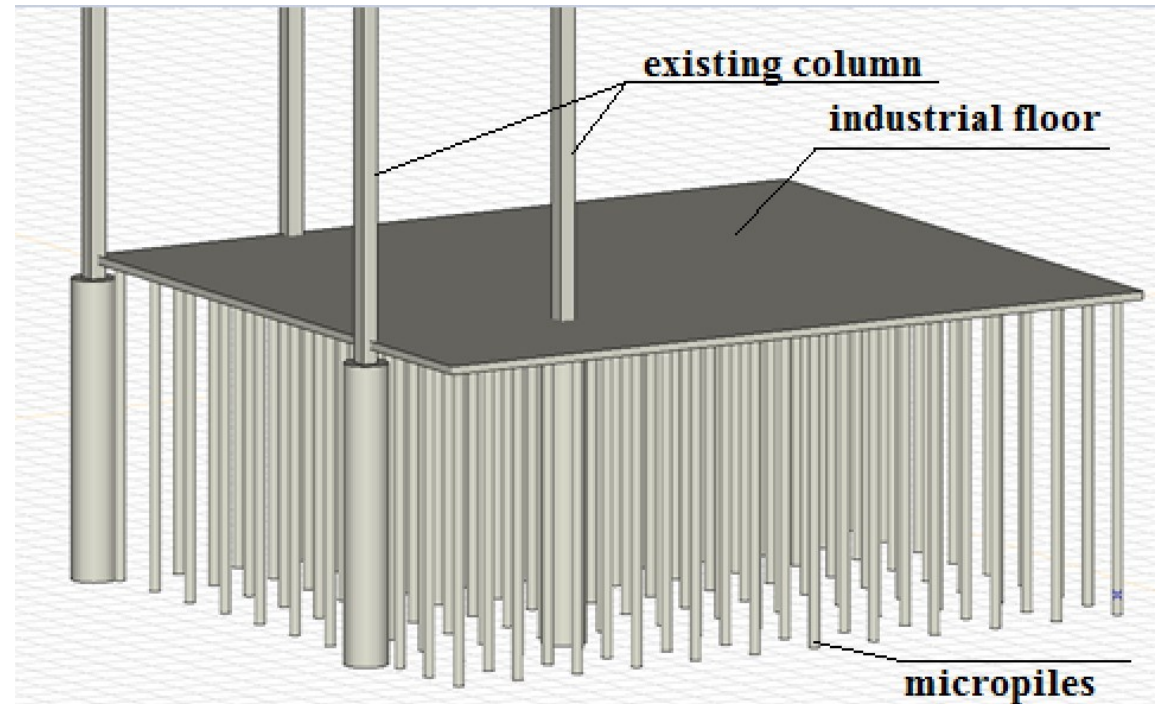

Fig. 9. Fragment of a numerical model of the warehouse flooring founded on micropiling. 
a)

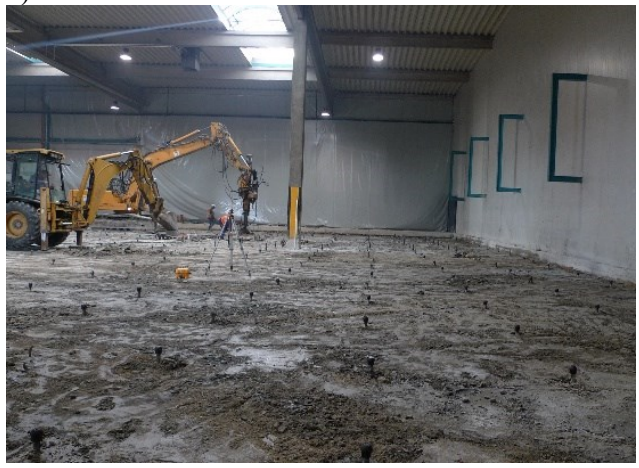

c)

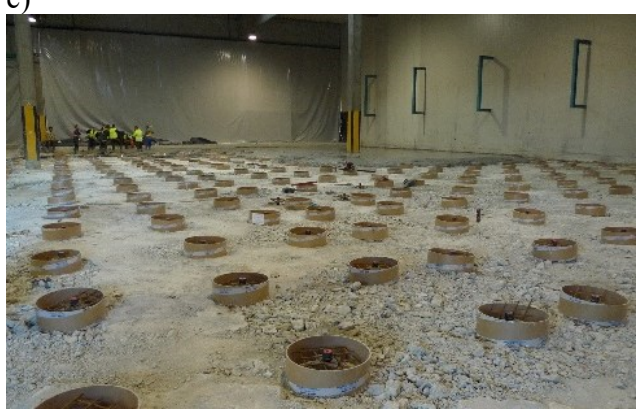

e)

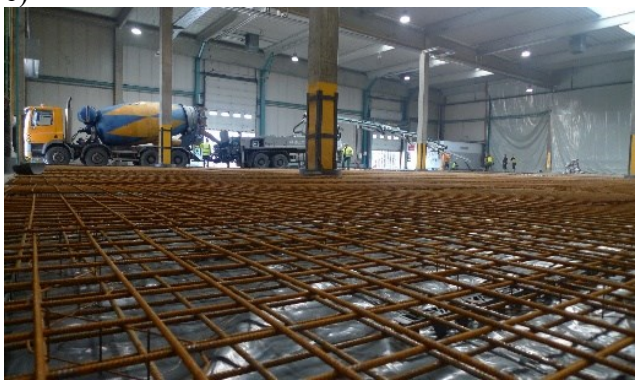

g)

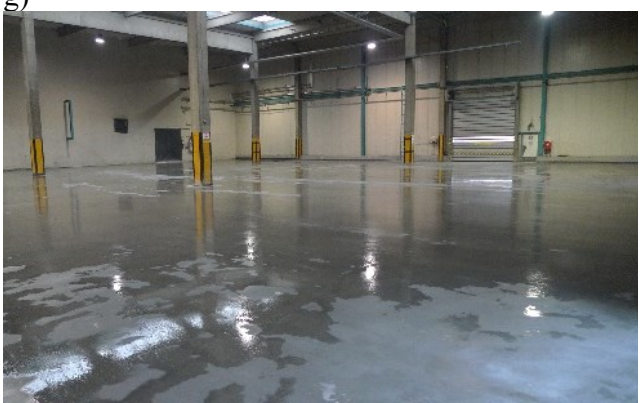

b)

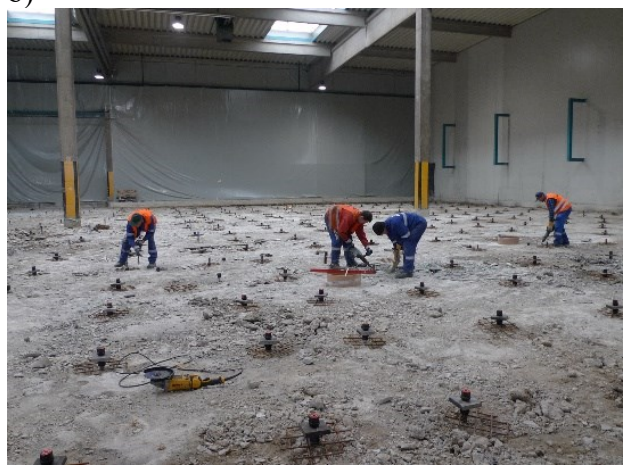

d)

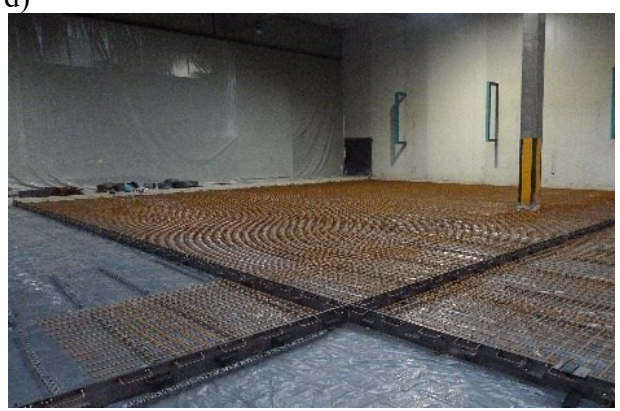

f)

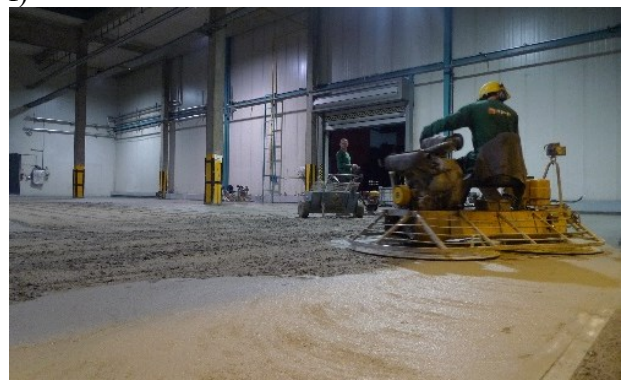

h)

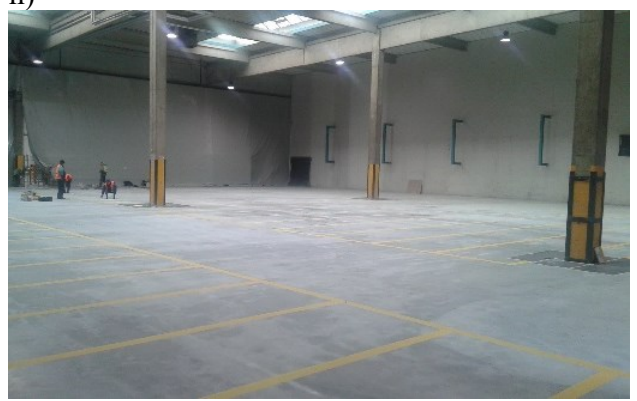

Fig. 10. Warehouse flooring construction stages: (a) micropile drilling; (b) reinforcement of the cap blocks; (c) lean concrete casting; (d) installation of the expansion joint profiles and reinforcement of the slab; (e) concrete slab casting; (f) floating; (g) warehouse floor shown following the construction; (h) warehouse floor shown as finished. 


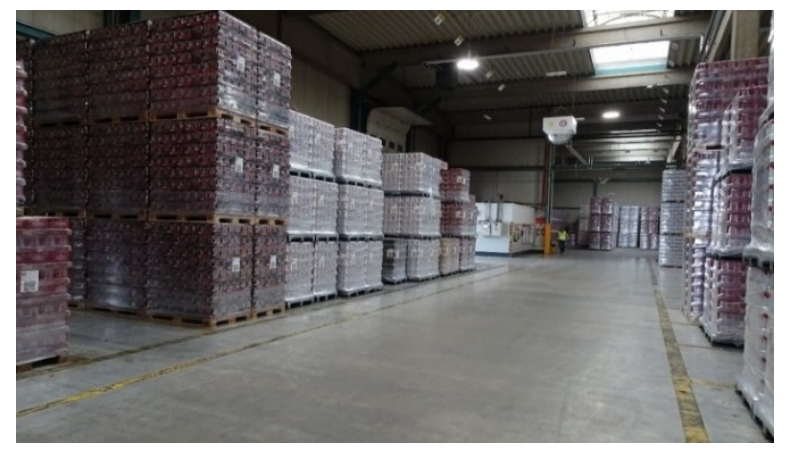

Fig. 11. View of the warehouse floor one year after its construction.

\section{Conclusions}

The warehouse floor system exposed to large-area loads interacted with the subsoil which featured a high thickness. It was necessary to survey the subsoil to a sufficient depth and perform a proof of ULS and SLS to meet the limit states involved. This paper demonstrated that, despite a good subsoil survey, the effect of highly deformable layers deposited several metres deep below the flooring, was neglected. This resulted in non-uniform settlement (up to $150 \mathrm{~mm}$ in depth) of the warehouse floor, with severe cracking of its surface. It was necessary to decommission the warehouse floor.

Prior to the construction of the new warehousing flooring-bearing slab, the geotechnical survey was repeated and followed by reinforcement of the subsoil with drilled micropiling. The micropiling was designed as a foundation for a $22 \mathrm{~cm}$ thick RF floor slab with top and bottom reinforcement meshes. To protect the large floor fields (each $21.0 \times 18.42 \mathrm{~m}$ in size) from shrinkage loads, the calculations of the warehouse floor included a temperature load and additional reinforcement of concrete with a dispersion of polypropylene fibres.

The test loading performed on eight finished micropiles and the monitoring of the finished warehouse floor from the start of its service in 2017 confirmed that the solutions designed for the repair were relevant.

\section{References}

1. P. Hajduk, Projektowanie podłóg przemysłowych (PWN, Warsaw, 2013) [in Polish]

2. H. Kreuter. Industriefussboden, Internationales Kolloqium, pp. 93-98 (1999)

3. Ł. Drobiec. Mauerwerk 21, pp. 332-342 (2017)

4. Ł. Drobiec, R. Jasiński, W. Mazur. Cement Wapno Beton 5, pp. 339-413 (2017) [in Polish]

5. R. Jasiński, Ł. Drobiec, A. Piekarczyk. Procedia Eng. 161, pp. 904-910 (2016)

6. R. Jasiński, Ł. Drobiec, A. Piekarczyk. Procedia Eng. 161, pp. 911-917 (2016)

7. PN-81/B-03020, Grunty budowlane. Posadowienie bezpośrednie budowli [in Polish]

8. Manual: Th. Zimmermann, A. Truty, A. Urbański, K. Podleś K: Theory. Zsoil. Manual, (Elmepress International \& Zace Services Ltd., Switzerland, 2011)

9. Titan, Przewodnik Projektowy (2018) [in Polish]

10. PN-EN 1997-1:2008. Eurocode 7. Part 1. Geotechnical design. General rules

11. PN-83/B-02482, Fundamenty budowlane - Nośność pali i fundamentów palowych [in Polish] 